Social Work \& Education

QSW\&E, 2021

UDC 364.04(477)

DOI: $10.25128 / 2520-6230.21 .1 .3$.

\section{Tatiana Skliar,}

$\mathrm{PhD}$ student, Academy of Labour, Social Relations and Tourism, Kyiv, Ukraine; tasha.skliar@gmail.com

ORCID ID: https://orcid.org/00000002-4969-888X
Skliar, T. (2021). Ethical standards for digital technology use in social work practice. Social Work and Education. Vol. 8, No. 1. TernopilAberdeen, 2021. pp. 42-50. DOI: 10.25128/25206230.21.1.3.

\section{ETHICAL STANDARDS FOR DIGITAL TECHNOLOGY USE IN SOCIAL WORK PRACTICE}

\author{
Article history: \\ Received: January 11, 2021 \\ 1st Revision: January 26, 2021 \\ Accepted: March 30, 2021
}

\begin{abstract}
Lockdown restrictions following the COVID-19 pandemic have led to restrictions on the services provision in social centers. It has become clear that the list of digital social work services should be expanded. Crisis counseling and psychological support, the so-called hotlines, were the first to be successfully established in the format of remote delivery of services to the population. Expanding the range of digital social work services is an important task, but the main prerequisite for the introduction of such services is the definition of ethical standards for the use of technology in the practice of social work.

The aim of this paper is to explore the ethical standards for digital technology use in social work practice. This paper focuses on ethical standards through providing an overview of literature for the accumulation of international experience and the formulation of recommendations on the ethical standards for digital technology use in social services.

The code of conduct should be designed to enhance social services providers' awareness of their ethical responsibilities when using technology; and inform social services providers, employers, and the public about practice standards pertaining to social services providers' use of digital technology. As new forms of technology continue to emerge, the standards should be adapted accordingly. The ethical standards should be considered as a general guidance on how to use digital technology in an ethical manner.

Our recommendations are that ethical standards should be incorporated in far greater depth on digital delivery of services than is currently the case, and that codes of conduct should be developed and deployed provided they can be seen to be effective. In tandem with these, an active discussion regarding the ethical framework in social work practice is urgently needed.
\end{abstract}

Key words: Ethical standards; digital technology in social work practice; social services providers; digital delivery of services; digital social work services; lockdown restrictions; COVID-19 pandemic. 


\section{Introduction}

Lockdown restrictions following the COVID-19 pandemic have led to changes on the services provision in social centers (Karagodina, Pozhidayeva \& Semigina, 2020; Semigina \& Skliar, 2020). The observations allows to conclude that the global pandemic has forced explorating options for providing digital social work services (distance-based, digital, tele- or online) due to the public health need to maintain physical distancing.

Contemporary social work practice faces the need to provide services to individual clients by using online counseling, telephone counseling, videoconferencing, selfguided web-based interventions, electronic social networks, mobile apps, automated tutorials, e-mail, text messages, and a host of other services (Barsky, 2017).

The use of technology has created new ways to interact and communicate with clients, raising fundamentally new questions about the meaning of the social workerclient relationship and ethical standards that should be developed and deployed. In addition, the various forms of technology to access, gather, and otherwise manage information about clients should be used. Social services providers have to maintain encrypted electronic records, store sensitive information on their smartphones and in the "cloud," and have the capacity to search for information about clients using Internet search engines. A new need arises to use technology in creative ways to address compelling social justice issues, organize communities, administer organizations, and develop social policy (Fitch, 2015).

The aim of this paper is to explore how digital technology may transform the nature of social work practice and expand social services providers' ability to assist people in need.

\section{Methodology}

We carried out the analysis of prior literature by using the keywords "ethical standards", "digital technology in social work practice", "social services providers", "digital delivery of services", "digital social work services". The method used for this study comprised of two stages. First, we selected the pool of review studies, and second, we discussed the outcomes of the review. To select studies for the review, we employed the technique of citation chaining to ensure the maximum coverage of articles. The data timeline was set to be 2008 to 2020 to ensure the coverage of articles published in the past decade. Using the abovementioned keywords, 118 research studies were found from the Google Scholar. Next, based on the inclusion and exclusion criteria the studies were read and shortlisted. The inclusion criteria are: empirical studies on ethical standards for digital technology use; studies published in peer-review journals; studies published in English. The exclusion criteria are: duplicate studies and studies with same digital object identifier; book chapters and dissertations. Then, the selection to arrive at the final pool of the articles to review was carried out. 
Also, the Codes of Ethics of the leading professional Associations such as American Counseling Association (ACA), American Psychological Association (APA) American Telemedicine Association (ATA) Association of Social Work Boards (ASWB), International Association of Schools of Social Work (IASSW), American National Association of Social Workers (NASW) were selected for review.

In our analysis, we used the notion that social services providers' ethical responsibilities refer to the three main dimensions: 1) provision information to the public; 2) service design and delivery; 3) gathering, management, storage and access to information about clients (NAWS, 2015). So, research findings are grouped around these three themes.

\section{Research results}

\section{Provision information to the public}

When social services providers use technology to provide information to the public, they shall take reasonable steps to ensure that the information is accurate, respectful, and consistent with the adopted code of ethics (ASWB, 2015). When communicating with the public using web sites, blogs, social media, or other forms of electronic communication, social services providers should make every effort to ensure that the information reflects the values, ethics, and mission of the profession. Social services providers should consult standards related to competence; conflicts of interest; privacy and confidentiality; respect; dishonesty, fraud, and deception; misrepresentation; solicitations; private conduct; and acknowledging credit for guidance (ATA, 2013).

The information for the public should come from trustworthy sources. the accuracy and appropriateness of the material should be ensured. Responsible personnel should periodically review information posted online to ensure that their professional credentials and other information are accurately portrayed and make reasonable effort to correct inaccuracies (APA, 2010).

\section{Designing and Delivering Services}

Technology may be used to facilitate various forms of services, including counseling, case management, support, and other social work functions. Also technology may be used to facilitate communication with clients, obtain information from clients, provide information to clients, and facilitate various interventions. When using technology to provide services, practitioner competence and the well-being of the client remain primary (Barak \& Grohol, 2011). Social services providers who use technology to provide services should evaluate their ability to assess the relative benefits and risks of providing social work services using reasonably ensure that digital social work services can be kept confidential (Finn \& Barak, 2010).

Key requirements for remote social work are: 1) the information provided by the client should only be accessible by those who require access; 2) confirmation of the 
identity of the client to whom services are provided electronically at the onset of each contact with the client (by providing the client with a password, passcode, or image that is specifically for the client's use when providing consent electronically; 3) maintaining clear professional boundaries (Reamer, 2013).

\section{Gathering, management, storage and access to information about clients}

Various forms of technology to gather, manage, and store client information can be used. When social services providers use technology to gather, manage, and store information, they must uphold ethical standards related to informed consent, client confidentiality, boundaries, and providing clients access to records (Online Therapy Institute, 2014).

As part of the informed consent process, social services providers shall explain to clients whether and how they intend to use electronic devices or communication technologies to gather, manage, and store client information

Risks of gathering, managing, and storing information electronically are identified as the following: 1) someone intentionally hacks the system and gains access to the data; 2) computers, smartphones, flash drives, external hard drives, or other devices used to gather and store the data are stolen or misplace; 3) information stored electronically may be subpoenaed for use during legal proceedings, just as with paper records; 4) electronic information may be unintentionally sent to the wrong person, especially when sending e-mail or text messages (Gupta \& Agrawal, 2012).

Social services providers should clearly delineate between personal and professional information when using personal technology to gather, manage, and store information about clients. This is important to maintain ethical boundaries with clients, maintain proper client files, and possibly protect the social worker's personal or other files from disclosure (Dowling \& Rickwood, 2013). When feasible, social services providers should consider using their professional or organization's electronic devices to gather, manage, and store information. If this is not feasible, then other means should be implemented, for example, the use of separate accounts, separate storage media or folders, et cetera. The clients generally have a right to access their records.

Social services providers who collect, manage, and store information electronically should take reasonable steps to ensure the privacy and confidentiality of information pertaining to clients. Electronic information should be stored in secure locations. Access should be limited to appropriate parties. When electronic files are backed up, reasonable precautions should also be taken to maintain confidentiality of the backed-up files.

Social services providers should be aware that some free services for gathering, managing, and storing data may not be as secure as fee-for-service options. For instance, when collecting data on some free survey services, the Internet Protocol addresses of survey respondents may be identifiable. If clients are using an online social network program to log on to the survey, their participation in the survey might be 
disclosed on their social networking site. Cloud storage has become technically appropriate and increasingly popular. Social services providers who use cloud storage should adhere to privacy and security standards (Barak et al., 2008).

Also, policies and procedures concerning on how to notify clients of any breach of their confidential records should be developed and disclosed (Richards \& Vegano, 2013).

\section{Existing guidelines and recommendations}

The international scholars, such as Kolmes (2014), Lamendola (2010), Schoech (2014), consider that the most often, attention is paid to recommendations on how to protect the confidentiality and privacy of all professionally acquired information. When using technology to deliver services, confidentiality policies and procedures consistent with relevant statutes, regulations, rules, and ethical standards should be established and maintained.

To help social services providers to maintain the best interest of the client as the primary professional obligation, the leading social workers' associations such as American National Association of Social Workers (NASW), American Association of Social Work Board (ASWB), American Counseling Association (ACA), International Association of Schools of Social Work (IASSW) and other professional associations have developed their guidelines and recommendations on the use of technology, based on their Codes of ethics.

It is worth mentioning separately the Global Social Work Statement of Ethical Principles issued by the International Association of Schools of Social Work (2018) sets the principles of the Ethical Use of Technology and Social Media.

The Paragraph 8 of this document states that social workers should recognize that the use of digital technology and social media (these include: counselling and research via email; videos; on-line self-help groups or use of Facebook and WhatsApp that may be used as stand alone or in conjunction with face-to-face interaction) may pose particular threats to the principles of confidentiality and privacy and must take the necessary precautions to guard against this. Informed consent must make such possible limits to confidentiality and privacy clear. It is the responsibility of the social workers to provide proof of ethical practice, irrespective of the mode of practice (IASSW, 2018).

The analysis reveals the absence of substantial differences between different guidelines. They demonstrate complete unanimity in their ethical principles regarding digital technology use.

\section{Concluding remarks}

There is no doubt that digital services delivery in social work practice can be effective. Digital social work services are a viable alternative to in-person care for a variety of clients, especially in the application of lockdown restrictions, nevertheless they also constitute certain challenges to the profession (Pentini \& Lorenz, 2020). 
Digital social work services should be integrated into the overall social care delivery system to ensure continuity of services. The implications of this, however, are more complex, as interventions need to be adapted to each context, and ethical standards are crucial.

Firstly, a special attention should be given to confidentiality and data privacy considerations. Social agencies increasingly use digital means to acquire, use, maintain, and store personal information. Digital format can improve performance of core functions, but potentially threaten privacy because data can be easily duplicated and transmitted to unauthorized people. Social services providers should respect personal privacy, and the protection of personal data, necessarily shared between individuals and institutions. The relationship between the social services providers and their clients is one of confidentiality and social services providers should take appropriate measures to ensure that clients data is not shared beyond the original transaction. Data protection is both a central issue for professional ethics and a fundamental human right. Data protection imposes obligations on social services providers to provide clients with detailed information about what will happen to the personal data that they collect. It also requires the organisations processing the data to ensure the data are properly protected, minimised, and destroyed when no longer needed.

Secondly, nowadays the social agencies participate in social media and other digital platforms for many reasons but primarily to communicate information about services and resources. Thus, ethical standards for digital technology use issued by different professional associations (IASSW, ACA, APA, ATA, ASWB, NASW) envision certain obligations on social services providers regarding provision information to the public. So, social services providers have an ethical obligation to the public on the proposed content. Thereby, the comprehensive guidelines should be placed to provide general guidance for social services providers of all types regarding ethical issues arising from social media and other digital platforms.

Thirdly, to provide digital social work services, existing social work practices will need to be organized and approached differently. When providing social work services using digital technology, social services providers shall inform the client of relevant benefits and risks. Possible benefits of providing social work services through electronic means include enhancing access to social work services that are unavailable in person because of geographical distance, clients' disabilities, or illnesses real-time monitoring of clients' status, when appropriate being able to respond to clients rapidly enhancing access to services because of clients' scheduling challenges providing more cost-effective delivery of social work services, ease of communication reducing the frequency of clients' travel to obtain social work services. Possible risks of providing social work services through electronic means include potential for technology failure and interruption of services potential for confidentiality breaches prevention of unauthorized use or unethical purposes higher cost of technology. Also, digital social 
service provision may not be suitable for all service users, for example when people have difficulties in accessing services (e.g. people with disabilities may require specific adaptations) or when people are not able to have private conversations due to crowded housing conditions.

Furthermore, one of the conditions for the expansion of digital social services is continuing education. Social services providers who use technology in their social work practice shall examine and keep current with relevant emerging knowledge. Social services providers should review relevant professional literature and guidelines, as well as attend relevant continuing education classes, seminars, workshops, webinars, other in-person and online courses. When examining research evidence, social workers should give precedence to research that meets prevailing professional methodological and ethical standards.

\section{References}

American Counseling Association (2014). ACA code of ethics. Retrieved from www.counseling.org/docs/ethics/2014-aca-code-of-ethics.pdf?sfvrsn=4

American Psychological Association (2010). Ethical principles of psychologists and code of conduct. Retrieved from www.apa.org/ethics/code/index.aspx

American Telemedicine Association (2013). Practice guidelines for video-based online mental health services. Retrieved from www.americantelemed.org/docs/defaultsource/standards/practice-guidelines-for-video-based-online-mental-healthservices.pdf? sfvrsn $=6$

Association of Social Work Boards (2015). Model regulatory standards for technology and social work practice. Retrieved from www.aswb.org/wpcontent/uploads/2015/03/ ASWB-Model-Regulatory-Standards-for-Technology-andSocial-Work-Practice.pdf

Barak, A., \& Grohol, J. M. (2011). Current and future trends in Internet-supported mental health interventions. Journal of Technology in Human Services, 29, 155-196.

Barak, A., Hen, L., Boniel-Nissim, M., \& Shapira, N. (2008). A comprehensive review and a meta-analysis of the effectiveness of Internet-based psychotherapeutic interventions. Journal of Technology in Human Services, 26, 109-160.

Barsky, A. E. (2017). Social work practice and technology: Ethical issues and policy responses. Journal of Technology in Human Services, 35, 1-12.

Dowling, M., \& Rickwood, D. (2013). Online counseling and therapy for mental health problems: A systematic review of individual synchronous interventions using chat. Journal of Technology in Human Services, 31, 1-21.

Finn, J., \& Barak, A. (2010). A descriptive study of e-counsellor attitudes, ethics, and practice. Counselling and Psychotherapy Review, 24(2), 268-277.

Fitch, D. (2015). A conceptual framework for information technology in social work practice. Advances in Social Work, 16, 15-30. 
Gupta, A., \& Agrawal, A. (2012). Internet counselling and psychological services. Social Science International, 28, 105-122.

IASSW (2018). Global Social Work Statement of Ethical Principles. Retrieved from https://www.iassw-aiets.org/wp-content/downloads/global-social-work-statement-ofethical-principles-2018/Global-Social-Work-Statement-of-Ethical-Principles-IASSW27-April-2018-01-English.pdf

Karagodina, O., Pozhidayeva, O., Semigina, T. (2020). Practice of social work in the conditions of quarantine restrictive measures: rapid appraisal and lessons. Social Work and Education, 7(4), 452-465.

Kolmes, K. (2014). My private practice social media policy. Retrieved from www.drkkolmes.com/docs/socmed.pdf

Lamendola, W. (2010). Social work and social presence in an online world. Journal of Technology in Human Services, 28, 108-119.

National Association of Social Workers (2015). Code of ethics of the National Association of Social Workers. Retrieved from www.naswdc.org/pubs/code/code.as

Online Therapy Institute (2014). Ethical framework for use of technology in mental health. Retrieved from http://onlinetherapy institute.com/ethical-training

Pentini, A.A., Lorenz, W. (2020). The Corona crisis and the erosion of 'the social' giving a decisive voice to the social professions. European Journal of Social Work, DOI: $10.1080 / 13691457.2020 .1783215$.

Reamer, F. G. (2013). Social work in a digital age: Ethical and risk management challenges. Social Work, 58, 163-172.

Reamer, F. G. (2015). Digital technology in social work. In Franklin, C. ed. Encyclopedia of social work online. New York and Washington, DC: Oxford University Press and NASW Press. doi:10.1093/acrefore/9780199975839.013.1160

Richards, D., \& Vigano, N. (2013). Online counseling: A narrative and critical review of the literature. Journal of Clinical Psychology, 69, 994-1011.

Schoech, R. (2014). Human services technology: Retrospective and perspective. Journal of Technology in Human Services, 32, 240-253.

Semigina, T., Skliar, T. (2020). The response of social work to the challenges of the COVID pandemic Paradigmatic view on the concept of world science. Toronto. Retrieved from https://doi.org/10.36074/21.08.2020.v1.56 


\section{ЕТИЧНІ СТАНДАРТИ ВИКОРИСТАННЯ ЦИФРОВИХ ТЕХНОЛОГІЙ В ПРАКТИЦІ СОЦІАЛЬНІЙ І РОБОТИ}

Tетяна Скляр, аспірантка, Академія праці, соціальних відносин та туризму, Київ, Україна; tasha.skliar@gmail.com

Анотація. Карантині обмеження в наслідок пандемії COVID-19 призвели до обмеження надання послуг у сочіальних ичентрах. Стало зрозуміло, щзо перелік цุифрових соціальних послуг потрібно розширювати. Кризове консультування та психологічна підтримка, так звані «гарячі лінї», першими були успішно впроваджені у форматі дистанційного надання послуг населенню. Розширення асортименту послуг иифрової соціальної роботи є важливим завданням, але головною передумовою впровадження таких послуг $\epsilon$ визначення етичних стандартів використання цчифрових технологій у практиці соціальної роботи.

Метою даної роботи є дослідження етичних стандартів використання цицфрових технологій у практищі сочуільної роботи. Ця стаття використовує огляд літератури для вивчення накопиченого міжнародного досвіду та формулює рекомендації щзодо етичних стандартів використання ичифрових технологій у сочіальних послугах.

Кодекс поведінки повинен бути розроблений для підвищення обізнаності постачальників соціальних послуг про свої етичні обов'язки при використанні цчифрових технологій; та інформування постачальників сочіальних послуг, роботодавців та громадськості про стандарти практики, щуо стосуються використання цчифрових технологій. Оскільки нові форми цчифрових технологій продовжують з'являтися, стандарти повинні постійно адаптуватися відповідно до змін. Етичні стандарти слід розглядати як загальне керівництво щзодо того, як використовувати циифрові технологї етично.

Наші рекомендації полягають у тому, щзо етичні стандарти повинні бути включені набагато ширше у практику дистаниійного надання сочіальних послуг, ніж зараз, і щзо кодекси поведінки повинні бути розроблені та застосовані для ефективного врегулювання питань дистанційного надання соціальних послуг. Поряд з ичим, терміново необхідно організувати активну дискусію щзодо етичних рамок у практиці соціальної роботи.

Ключові слова: етичні стандарти; цчифрові технології в практиці соціальної роботи; постачальники соціальних послуг; дистанційне надання послуг; цуифрові послуги сочіальної роботи; обмеження блокування; пандемія COVID-19. 